\title{
$\mathrm{CO}_{2}$ 固定化를 위한 電氣爐製鋼슬래그의 칼슘成分 浸出
}

\author{
中尹起 炳 \\ 仁川大學校 新素材工學科 \\ The Extraction of $\mathrm{Ca}$ in Electric arc Furnace Slag for $\mathrm{CO}_{2}$ Sequestration \\ 中Ki-Byoung Youn \\ Department of Materials Science \& Engineering, Incheon University \\ 요 약 \\ 지구온난화 원인으로 지목되고 있는 $\mathrm{CO}_{2}$ 가스를 저감시키기 위한 방안 중의 하나로 칼슘이나 마그네슘 등을 함유하는 천연규산 \\ 염 광물의 탄산염화가 제안되고 있다. 전기로제강슬래그는 칼슘, 마그네슘 등 을 주성분으로 하는 규산염들로 구성되고 있어, 이 슬 \\ 래그를 천연규산염 광물 대신에 탄산염화의 대상원료로 사용하면 $\mathrm{CO}_{2}$ 가스저감은 물론 탄산칼슘과 같은 산업원료를 제조, 활용할 \\ 수 있는 가능성이 있다. 전기로제강슬래그 탄산염화에 의한 탄산칼슘 제조공정은 칼슘성분의 분리단계와 분리된 칼슘성분의 탄산염 \\ 화단계로 구성된다. 슬래그 중의 칼슘성분 분리를 위한 초산침출 연구결과는 이미 보고되어 있으며 분리된 침출용액 중의 칼슘이온 \\ 의 탄산염화는 고압의 $\mathrm{CO}_{2}$ 가스 하에서도 반응속도가 매우 느린 것으로 예측되고 있다. 본 연구에서는 보다 효율적인 침출 및 탄산 \\ 염화 공정의 개발을 위하여 염산수용액 침출에 의한 칼슘성분 분리에 관한 실험을 수행하였으며 그 침출결과를 초산침출 실험결과 \\ 와 비교, 분석하였다. 용액 중의 $\mathrm{Ca}^{2+}$ 의 $\mathrm{CO}_{2}$ 가스에 의한 탄산염화 반응에 대한 열역학적 자료를 통하여 용액의 $\mathrm{pH}$ 에 따른 $\mathrm{Ca}^{2+}$ 과 \\ $\mathrm{CaCO}_{3}$ 의 phase boundary를 고찰하였다. 슬래그 중의 칼슘성분 분리를 위해서는 염산이 초산에 비하여 더욱 효율적인 침출용매이 \\ 며, 염산을 침출용매로 사용 시는 침출용액 중의 미반응산의 회수 및 재순환이 유리할 것으로 기대된다.
}

주제어 : 이산화탄소, 고정화, 전기로제강슬래그, 침출, 칼슘

\begin{abstract}
Mineral carbonation has been proposed as a possible way for $\mathrm{CO}_{2}$ sequestration. The electric arc furnace slags consist of calcium, magnesium and aluminum silicates in various combinations. If they could be used instead of natural mineral silicates for carbonation, considerable energy savings and $\mathrm{CO}_{2}$ emissions reductions could be achieved. Indirect aqueous carbonation of the slags consists of two steps, extraction of calcium and carbonation. Acetic acid leaching of electric arc furnace slags had been already studied to extract $\mathrm{Ca}$ in them, but it was reported that the carbonation of the extracted $\mathrm{Ca}^{2+}$ in the leached solution would suffer from too slow kinetics, even at high pressure of $\mathrm{CO}_{2}$. In this work, to develop more efficient extraction of the electric arc furnace slags, hydrochloric acid leaching to separate calcium from them was studied, and the results were compared with the acetic acid ones. The phase boundary between $\mathrm{Ca}^{2+}$ and $\mathrm{CaCO}_{3}$ in the solution with $\mathrm{pH}$ was determined by thermodynamic calculations. Hydrochloric acid was more effective than acetic acid for the extraction of $\mathrm{Ca}$ in electric arc furnace slag, and there is a possibility to recycle an unreacted hydrochloric acid in the leached solution by electrolysis or evaporation.
\end{abstract}

Key words : Carbon dioxide, Sequestration, Electric arc furnace slag, Extraction, calcium

\footnotetext{
* Received : February 23, 2010 • 1st Revised : April 7, 2010 • 2nd Revised : December 27, $2012 \cdot$ Accepted : February 8, 2013

₹Corresponding Author : Ki-Byoung Youn (E-mail: kbyoun@incheon.ac.kr)

Major of Advanced Materials Engineering, University of Incheon, 119 Academy-ro, Yeonsu-gu, Incheon, 406-772, Korea

Tel : +82-32-835-8275/ Fax : +82-32-835-0778

(C) The Korean Institute of Resources Recycling. All rights reserved. This is an open-access article distributed under the terms of the Creative Commons Attribution Non-Commercial License (http://creativecommons.org/licenses/by-nc/3.0/), which permits unrestricted non-commercial use, distribution and reproduction in any medium, provided the original work is properly cited.
} 


\section{1. 서}

지구온난화가스는 에너지분야를 비롯한 각종 산업분 야에서 발생하는 이산화탄소를 비롯하여 메탄, 아산화 질소, 불화물가스, 육불화황 등 6대 온실가스로 구분되 고 있으며, 국제간의 기후변화협약에 따라 의무적으로 배출량을 저감시켜야 될 실정에 있어 온실가스저감기술 개발에 관심이 집중되고 있다. 20세기 들어와 산업발전 에 따른 에너지소비량이 증가함에 따라 이산화탄소의 대기 중의 농도는 $350 \mathrm{ppm}$ 이상으로 급격히 증가되었 으며 이러한 증가추세는 계속될 것으로 예측되고 있다. 화석연료의 계속되는 사용과 무제한 경제성장에 의해 대 기 중의 $\mathrm{CO}_{2}$ 의 농도가 $1,000 \mathrm{ppm}$ 을 넘어서면, 2,100 년 에는 적어도 지금보다 $4^{\circ} \mathrm{C}$ 이상의 지구온도 상승을 가 져올 것이며, 이러한 지구온난화는 결과적으로 예기치 못 한 해양의 $\mathrm{pH}$ 감소, 해수면 상승, 대양난한류 순환의 붕괴, 생태계 파괴 등의 기후변화에 의한 재앙이 일어 나 결과적으로 지구종말의 결과를 초래할 수 있다.1) $\mathrm{CO}_{2}$ 가스저감기술은 배출저감기술, 분리포집기술, 변환 이용기술 등으로 구분할 수 있는데, 이러한 기술 중에 서도 $\mathrm{CO}_{2}$ 가스저감 및 산물활용이 가능한 변환이용기술 개발은 에너지와 자원이 부족한 국내실정에 비추어 볼 때 매우 중요한 기술개발과제이다. 최근에, 발생된 $\mathrm{CO}_{2}$ 가스의 고정화 및 전환산물의 자원화를 위한 한 방법으 로 칼슘이나 마그네슘을 탄산염화 하여 $\mathrm{CO}_{2}$ 를 고정화 시키고 고정화산물인 탄삼염을 산업원료로 이용하려는 기술개발이 국내 - 외에서 활발히 진행되고 있다. ${ }^{23)}$ 탄 산칼슘은 제지산업에서 중요한 원료로 사용되고 있으나, 석회석을 원료로 사용하여 제조하는 공정 중의 하소과 정에서 약 $0.65 \mathrm{~kg} \mathrm{CO} 2 / \mathrm{kg} \mathrm{CaCO}$ 의 $\mathrm{CO}_{2}$ 를 발생시키 고 있다. 탄산칼슘의 원료가 되는 석회석을 calcium silicate 광물로 대체한다면 하소과정이 필요없어 $\mathrm{CO}_{2}$ 발생량이 없고 오히려 탄산염화 공정 중에 타 산업에서 배출된 $\mathrm{CO}_{2}$ 를 흡수시켜 이론적으로 약 $0.44 \mathrm{~kg} \mathrm{CO} / \mathrm{kg}$ $\mathrm{CaCO}_{3}$ 정도의 $\mathrm{CO}_{2}$ 저감효과를 이룰 수 있다. 또한 에 너지 측면을 고려하여 보면 석회석을 원료로 사용하는 경우에는 $2,669 \mathrm{~kJ} / \mathrm{kg} \mathrm{CaCO} 3$ 에너지가 소모되는 반면 에 calcium silicate 광물의 경우에는 불과 $223 \mathrm{~kJ} / \mathrm{kg}$ $\mathrm{CaCO}_{3}$ 가 소모되는 것으로 예측되고 있어 막대한 에너 지 절감효과를 거둘 수 있는 가능성이 있다. ${ }^{4)}$ 2002년 기준 세계 총 PCC (Precipitated Calcium Carbonate) 소비량은 약 600 만톤 정도이며 이의 제조공정 에서 발 생되는 $\mathrm{CO}_{2}$ 가스는 약 400 만톤으로 추산할 수 있으며, calcium silicate를 원료로 사용하여 제조할 수 있다면 오히려 타 산업분야에서 발생된 약 300 만톤의 $\mathrm{CO}_{2}$ 가스 를 저감시킬 수 있어 총 700 만톤/년의 $\mathrm{CO}_{2}$ 가스 저감효 과를 가질 수 있으며 소비에너지도 약 $1 / 10$ 로 줄일 수 있어 국내 - 외 적으로 파급효과가 클 것으로 기대 된다. 국내 제강업계에서는 년간 수백만톤 이상의 제강 슬래그가 발생되고 있는데 이 슬래그의 주구성물질은 $\mathrm{CaO}$ 를 함유하고 있는 calcium silicate 이므로, 이 슬 래그로부터 $\mathrm{Ca}$ 성분을 분리하여 $\mathrm{CO}_{2}$ 가스로 탄산염화 시 키면 막대한 량의 $\mathrm{CO}_{2}$ 저감 및 에너지절감과 자원에 고부가가치화를 부여할 수 있는 가능성이 있다. 그러나 이의 실현을 위해서는 $\mathrm{Ca}$ 성분의 효율적 분리기술 및 $\mathrm{CO}_{2}$ 에 의한 탄산염화 반응의 느린 반응속도, 낮은 전환 율 등의 문제점을 해결할 수 있는 기술개발이 필요한 실정이다. 현재 제강슬래그의 침출, 탄산염화공정에 의 하여 $\mathrm{CO}_{2}$ 를 고정화하는 비용은 \$80 \$90/Ton $\mathrm{CO}_{2}$ 로 계산되어 육상이나 해상저장법 등에 의한 $\mathrm{CO}_{2}$ 고정화 처리비용 $\left(\$ 10\right.$ 미만/Ton $\left.\mathrm{CO}_{2}\right)$ 에 비하여 매우 높아 경제 성이 부족하다. ${ }^{5)}$ 그러나 탄산염화에 의한 $\mathrm{CO}_{2}$ 고정화 처리비용은 고정화 처리시설의 scale, 처리공정에서의 pulp density, 생산된 탄산염의 가격 등 여러 요인에 의 하여 크게 달라질 수 있어(6) 이에 대한 많은 연구들이 진행되고 있다. 전기로제강슬래그 탄산염화에 의한 탄 산칼슘 제조공정은 칼슘성분의 분리단계와 분리된 칼슘 성분의 탄산염화 단계로 구성된다. 슬래그 중의 칼슘성 분 분리를 위한 초산침출에 관한 해외연구결과는6) 이 미 보고되어 있으나, 분리된 침출용액 중의 칼슘이온의 탄산염화는 이론적으로는 고압의 $\mathrm{CO}_{2}$ 가스 하에서도 반 응속도가 매우 느린 것으로 예측되고 있다. 초산침출에 의하여 $\mathrm{Ca}$ 성분을 분리하는 경우는, $\mathrm{pH}$ 가 낮은 산용액 에서는 칼슘이온의 탄산염화반응은 진행되기 어려우므 로 산침출 용액의 $\mathrm{pH}$ 증가를 위하여 $\mathrm{NaOH}$ 등의 첨가 제를 사용하므로 침출용액의 재순환이 어려워 처리규모 및 공정의 경제성 문제를 야기시킬 수 있다. 산침출 과 정 후 미반응된 여분의 산을 회수, 재순환하기 위하여 는 일반적으로 간단한 증류법 즉, 증발과 응축 방법을 사용하는데 여러 종류의 산 중에서 염산이 가장 낮은 온도 $\left(48 \sim 110^{\circ} \mathrm{C}, 38 \sim 20 \mathrm{wt} \%\right.$ solution)에서 증발 가능 하다. 염산은 초산에 비하여 칼슘성분 침출에 더욱 효 율적인 침출용매이며, 염산을 침출용매로 사용 시는 침 출용액 중의 미반응산의 회수 및 재순환이 유리할 수 있다.

따라서, 본 연구에서는 전기로제강슬래그 $\mathrm{Ca}$ 성분의 
보다 효율적인 침출 가능성을 알아보기 위하여 염산수 용액 침출에 의한 칼슘성분 분리에 관한 기초실험을 수 행하여 그 침출결과를 초산침출 실험결과와 비교, 분석 하고, 열역학적 기초자료를 이용하여 용액 중의 칼슘이 온의 $\mathrm{CO}_{2}$ 가스에 의한 $\mathrm{CaCO}_{3}$ 로의 석출에 대한 이론적 고찰을 수행코자 한다.

\section{2. 시료 및 실험방법}

\section{1. 시료}

본 실험에 사용된 시료는 전기로제강공정의 부산물로 회수된 전기로제강슬래그로서 Jaw crusher 와 Hammer crusher를 사용하여 파쇄하고, 파쇄산물을 Ball mill로 분쇄, 입도별로 분리하여 평균입도 $120 \mu \mathrm{m}$ 의 시료를 실 험에 사용하였다. Table 1 및 Fig. 1은 각각 시료의 화학조성분석 및 $\mathrm{X}$ 선회절분석 결과이며, $\mathrm{Ca}$ 성분함량은 $15.18 \%, \mathrm{Fe}$ 성분함량은 $21.61 \%$ 를 보이고 있다.

\section{2. 실험방법}

전기로제강슬래그 중에 함유된 $\mathrm{Ca}$ 성분의 분리를 위 하여 초산 및 염산수용액을 사용한 침출실험은 Fig. 2 에 보인 침출장치를 사용하여 수행하였다. 침출장치는

Table 1. Chemical compositions of sample

\begin{tabular}{|c|c|}
\hline element & composition(\%) \\
\hline $\mathrm{Ca}$ & 15.18 \\
\hline $\mathrm{Fe}$ & 21.61 \\
\hline $\mathrm{Mg}$ & 4.99 \\
\hline $\mathrm{Mn}$ & 4.64 \\
\hline $\mathrm{Al}$ & 0.85 \\
\hline $\mathrm{Ti}$ & 0.55 \\
\hline $\mathrm{S}$ & 0.17 \\
\hline
\end{tabular}

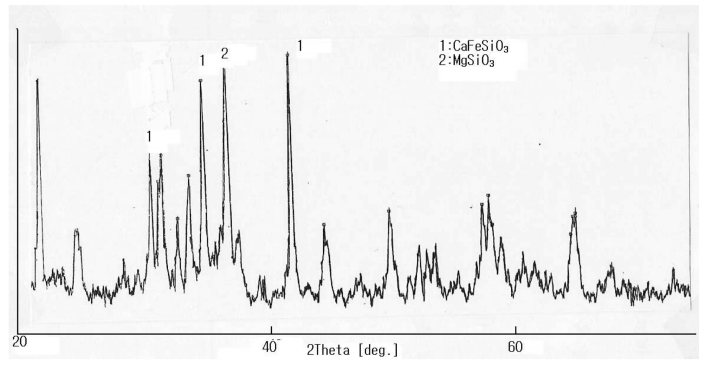

Fig. 1. XRD pattern of the sample.

J. of Korean Inst. Resources Recycling Vol. 22, No. 1, 2013
4구침출반응조(1 l glass reactor), 응축시스템, 항온수조, 교반기 등으로 구성되어 있다. 일정농도의 염산(또는 초 산) 수용액 $300 \mathrm{~m} /$ 를 침출반응조에 넣고, 일정온도로 유 지되고 있는 항온수조 내에서 침출온도 까지 승온시킨 후, $1 \mathrm{l} / \mathrm{min}$ 의 질소를 용액 내에 유입시키면서 $400 \mathrm{rpm}$ 의 교반속도로 교반하여 정해진 온도가 안정적으로 유 지될 때, $5 \mathrm{~g}$ 의 슬래그 시료분말을 용액에 투입하면서 침출을 시작하였다. 일정 침출시간 경과 시 마다 약 $5 \mathrm{ml}$ 의 침출용액을 채취하여 syringe membrane filter $(0.45 \mu \mathrm{m}$ pore size)를 사용하여 여과하여 액체분석시료를 채취하고, 한국기초과학지원연구원에서 ICP-AES에 의하여 용액 중의 각 성분의 침출이온농도를 분석하였다.

\section{3. 실험결과 및 고찰}

Calcium silicate mineral을 산침출 시 $\mathrm{Ca}$ 성분의 침 출반응은 다음과 같이 표시될 수 있다.

$$
\mathrm{CaSiO}_{3(\mathrm{~s})}+2 \mathrm{H}^{+}{ }_{(\mathrm{aq})} \rightarrow \mathrm{Ca}^{2+}{ }_{(\mathrm{aq})}+\mathrm{H}_{2} \mathrm{O}_{(\ell)}+\mathrm{SiO}_{2(\mathrm{~s})}
$$

이 $\mathrm{Ca}^{2+}$ 침출반응은 $156^{\circ} \mathrm{C}$ 이하의 온도에서 열역학적 으로 가능한 발열반응이다. 전기로제강슬래그 중의 $\mathrm{Ca}$ 성분을 분리하기 위하여 산침출하는 과정에서 $\mathrm{Fe}, \mathrm{Si}$ 등의 여러다른 성분 들도 침출된다. 특히 $\mathrm{Fe}$ 성분은 침 출용액 중의 $\mathrm{Ca}$ 성분의 탄산염화 과정에서 생성되는 탄 산칼슘의 순도 및 색도에 큰 영향을 미치는 불순물로 작용하므로 용액 중에 가능한 적은량의 침출이 바람직 하다. 본 침출연구에서는 침출조건에 따른 $\mathrm{Ca}$ 성분의 침 출조사와 아울러 $\mathrm{Fe}$ 성분의 침출경향도 조사, 분석하였다.

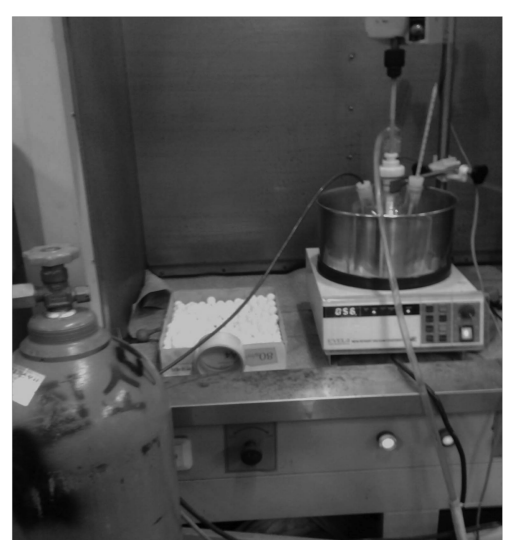

Fig. 2. Experimental dissolution system. 


\section{1. $\mathrm{Ca}$ 성분 침출}

전기로제강슬래그의 $\mathrm{Ca}$ 성분 침출에 미치는 산농도의 영향을 알아보기 위하여 침출온도 $70^{\circ} \mathrm{C}$ 에서, 초산의 경 우는 $4 \mathrm{wt} \%, 10 \mathrm{wt} \%, 20 \mathrm{wt} \%, 33.3 \mathrm{wt} \%$, 염산의 경 우는 $0.5 \mathrm{~N}, 1 \mathrm{~N}, 1.5 \mathrm{~N}, 2 \mathrm{~N}$ 의 농도에서 침출실험을 수행하였으며 실험결과를 Fig. 3과 Fig. 4에 나타내었다. 그림에서 보는바와 같이 초산의 경우, 산농도가 증가할 수록 침출도 증가하고 있으나, $33.3 \mathrm{wt} \%$ 농도에서의 침 출결과가 $20 \mathrm{wt} \%$ 보다 낮은 결과를 보이고 있다. 이는 높은 온도에서의 산침출 과정에서 나타나는 겔상태의 실리카 형성이 높은 농도에서 더욱 증가하기 때문인 것 으로 추측된다. 이에 비하여 염산침출의 경우는 침출용 액 중의 염산농도가 증가할수록 $\mathrm{Ca}$ 성분 침출도 증가하 고 있으나 $1 \mathrm{~N}$ 이상의 농도에서는 $\mathrm{Ca}$ 성분 침출에 큰 영향을 미치지 않고 있음을 보이고 있다.

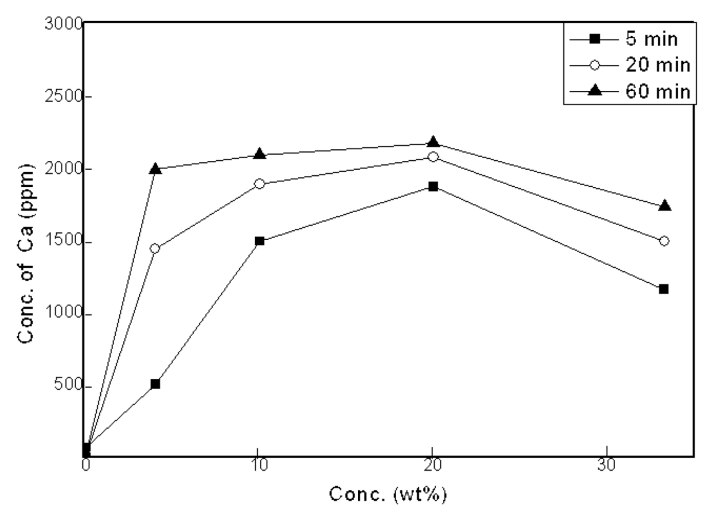

Fig. 3. Effect of acetic acid concentration in the extraction of $\mathrm{Ca}$ from the electric arc furnace $\operatorname{slag}\left(70^{\circ} \mathrm{C}, 120 \mu \mathrm{m}\right.$, $400 \mathrm{rpm})$.

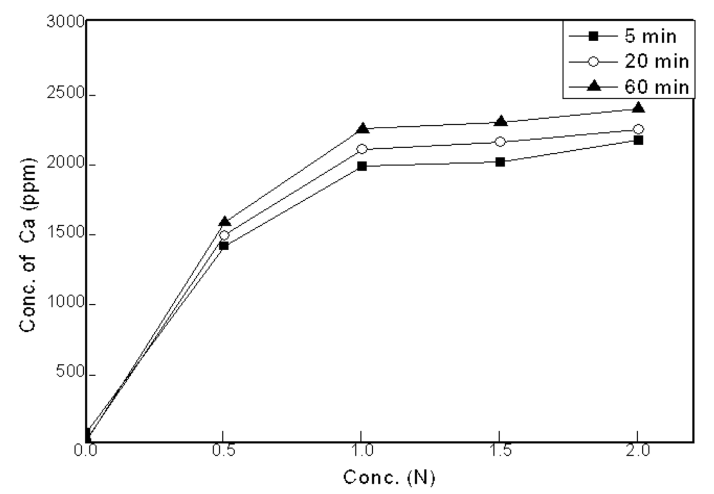

Fig. 4. Effect of hydrochloric acid concentration in the extraction of $\mathrm{Ca}$ from the electric arc furnace $\operatorname{slag}\left(70^{\circ} \mathrm{C}, 120 \mu \mathrm{m}, 400 \mathrm{rpm}\right)$.
Fig. 5와 Fig. 6은 각각 $33.3 \mathrm{wt} \%$ 초산과 $2 \mathrm{~N}$ 염산 수용액에서 시료를 침출 시, 침출온도에 따른 $\mathrm{Ca}$ 성분의 침출을 조사한 결과이다. 초산침출의 경우, 침출시간이 5 분 이내인 반응초기에는 침출온도가 증가함에 따라 침 출속도도 증가하여 $60^{\circ} \mathrm{C}$ 에서 최대의 침출속도를 보이 고 있으나, 그 이상의 침출온도 에서는 $\mathrm{Ca}$ 성분의 침출 속도 및 침출율은 오히려 감소하는 경향을 나타내고 있 다. 침출시간이 20 분, 60 분으로 증가하면 침출경향은 비 슷하나 침출속도는 $50^{\circ} \mathrm{C}$ 에서 최대를 보이며 침출시간 60 분에서 $\mathrm{Ca}^{2+}$ 농도가 $2,300 \mathrm{ppm}$ 정도에 달해 약 $90 \%$ 이상의 침출율을 보이고 있다. 전기로제강슬래그 중의 $\mathrm{Ca}$ 성분은 실리카 matrix 내의 미세기공을 통하여 침출, 분리되며 이 과정에서 다공질의 비정질실리카가 생성된 다. 산침출 과정에서 실리카의 일부도 용해가 일어나며 이 용해된 실리카는 침출온도가 높은 경우에는 겔상태 를 형성하게 된다. 따라서 침출온도가 $70^{\circ} \mathrm{C}$ 이상으로

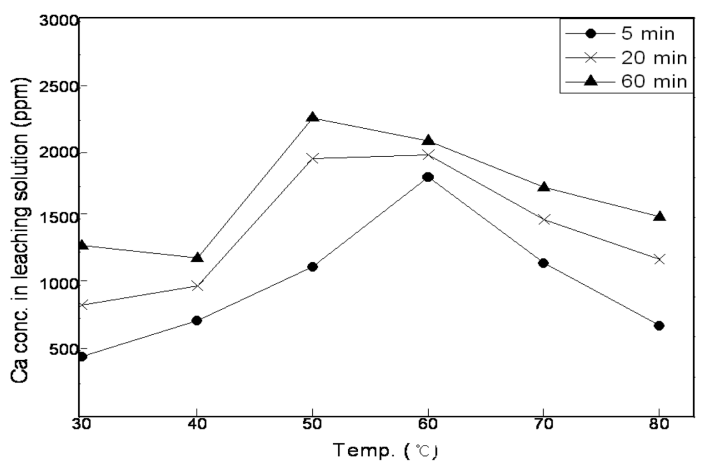

Fig. 5. Effects of leaching temperature on the extraction of $\mathrm{Ca}$ in the electric arc furnace $\operatorname{slag}\left(33.3 \mathrm{wt} \% \mathrm{CH}_{3}\right.$ $\mathrm{COOH}, 120 \mu \mathrm{m}, 400 \mathrm{rpm}$ ).

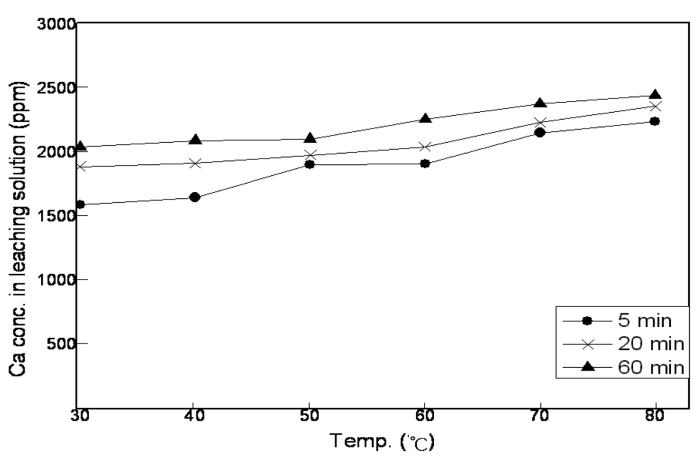

Fig. 6. Effects of leaching temperature on the extraction of $\mathrm{Ca}$ in the electric arc furnace $\operatorname{slag}(2 \mathrm{~N} \mathrm{HCl}, 120 \mu \mathrm{m}$, $400 \mathrm{rpm})$. 
증가하면 침출되는 실리카는 겔상태를 형성하여 반응표 면에서의 점도를 증가시켜 반응표면까지의 산 이온의 확산이 어려워지기 때문에 침출온도가 $70^{\circ} \mathrm{C}, 80^{\circ} \mathrm{C}$ 로 증가함에 따라 침출속도 및 침출율은 감소하는 경향을 보이고 있다. ${ }^{7}$ 초기반응속도가 최대치를 나타낸 침출온 도 $60^{\circ} \mathrm{C}$ 의 경우, 침출시간이 증가할수록 침출속도는 감 소하여 침출시간 60 분에서는 침출용액중의 $\mathrm{Ca}^{2+}$ 농도가 $50^{\circ} \mathrm{C}$ 의 경우보다도 더 낮은 값을 보이고 있는데, 이러 한 결과로 볼 때, 침출온도 $60^{\circ} \mathrm{C}$ 의 경우에서도 $70^{\circ} \mathrm{C}$ 및 $80^{\circ} \mathrm{C}$ 의 경우에 비해서는 적은 양이지만 반응시간이 증가할수록 겔상태의 실리카 형성이 이루어지고 있는 것으로 추정된다. 염산수용액 침출의 경우는 초산침출 의 경우와는 달리, 침출온도가 증가할수록 침출속도 및 침출율은 계속 증가함이 관찰되고 있으며 특히 침출온 도가 높은 $70^{\circ} \mathrm{C}$ 및 $80^{\circ} \mathrm{C}$ 의 경우에서 매우높은 침출속 도를 나타내어 5 분 이내의 짧은시간에 약 $80 \%$ 이상의 침출율을 보이고있다. 염산의 경우는 초산에 비하여 침 출속도가 매우 빨라 겔상태의 실리카에 의한 침출영향 이 상대적으로 적어 높은 침출온도에서 초산의 침출경 향과는 다른 결과를 보이는 것으로 추정된다.

전기로제강슬래그의 $\mathrm{Ca}$ 성분 침출에 미치는 침출시간 의 영향을 알아보기 위하여 $30^{\circ} \mathrm{C}, 50^{\circ} \mathrm{C}, 70^{\circ} \mathrm{C}$ 의 침출 온도에서 침출시간을 변화시키면서 침출정도를 조사하 였다. Fig. 7에서 보는바와 같이 초산침출의 경우 침출 온도가 낮은 $30^{\circ} \mathrm{C}$ 에서는 2 시간 까지는 침출시간이 증 가함에 따라 $\mathrm{Ca}$ 성분의 침출도 증가하여, 침출용액 중의 $\mathrm{Ca}^{2+}$ 농도는 약 $1,500 \mathrm{ppm}$ (약 $65 \%$ 침출율)에 도달하나 그 이상 침출시간을 증가시켜도 더 이상의 $\mathrm{Ca}$ 성분 농 도의 증가는 관찰되지 않았다. 침출온도 $50^{\circ} \mathrm{C}$ 의 경우에 서는 초기침출반응속도는 매우 빠르며 5 분 이내에 약 $1,200 \mathrm{ppm}$ (약 $52 \%$ 침출율) 정도의 $\mathrm{Ca}$ 침출 농도를 보 이고 있으며, 침출시간이 증가함에 따라 침출반응이 계 속 진행되어 60 분 침출 시 $2,300 \mathrm{ppm}$ (약 $91 \%$ 침출율) 에 도달하고 그 이상의 침출시간에서는 거의 비슷한 침 출농도를 보이고 있다. 한편 침출온도가 $70^{\circ} \mathrm{C}$ 로 증가하 면 침출반응 초기에는 매우 빠르게 $\mathrm{Ca}$ 성분의 침출이 일어나나, 침출시간이 더욱 길어지면 $\mathrm{Ca}$ 침출속도는 감 소하는 경향을 나타내고 있으나 침출율은 꾸준히 증가 하여 4 시간 침출시 $50^{\circ} \mathrm{C}$ 경우와 비슷한 침출율을 보이 고 있다. 염산침출의 경우에는 Fig. 8에서 보는 바와 같이 초기침출반응속도가 매우 커서 침출시간 5 분 이내 에 반응온도 $30^{\circ} \mathrm{C}$ 에서는 약 $70 \%, 50^{\circ} \mathrm{C}$ 이상에서는 약 $90 \%$ 정도의 침출율을 보이고 있다. 침출시간이 더욱 증

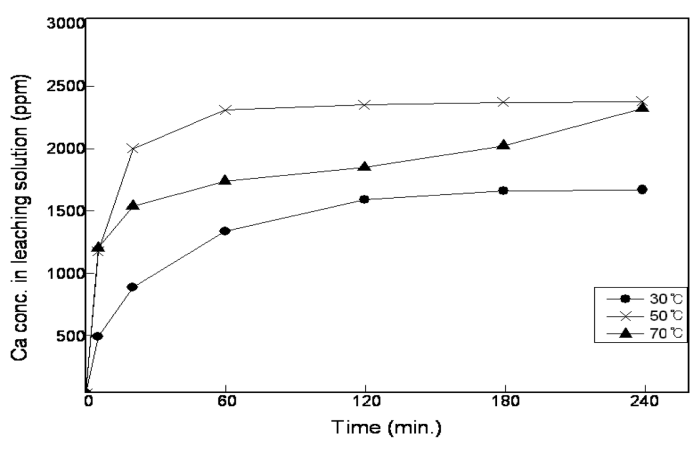

Fig. 7. Effects of leaching time on the extraction of $\mathrm{Ca}$ in the electric arc furnace slag ( $33.3 \mathrm{wt} \% \mathrm{CH}_{3} \mathrm{COOH}, 120 \mu \mathrm{m}$, $400 \mathrm{rpm}$ ).

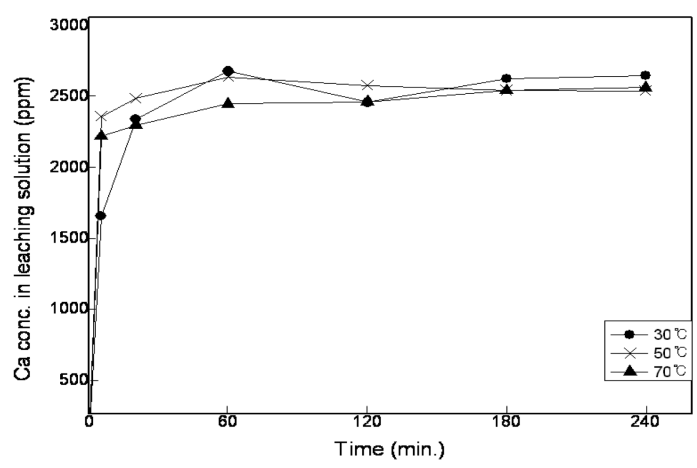

Fig. 8. Effects of leaching time on the extraction of $\mathrm{Ca}$ in the electric arc furnace slag $(2 \mathrm{~N} \mathrm{HCl}, 120 \mu \mathrm{m}$, $400 \mathrm{rpm})$.

가함에 따라 침출반응은 계속 진행되어 20 분이상 침출 시 $95 \%$ 이상의 침출율에 도달한 후 침출시간이 더욱 증가하여도 침출용액 중의 $\mathrm{Ca}$ 성분 농도는 비슷한 값으 로 유지되고 있다.

이상의 실험결과를 종합해 보면, 전기로제강슬래그로 부터 $\mathrm{Ca}$ 성분 분리를 위해서 초산수용액을 사용할 경우 는 $50^{\circ} \mathrm{C}$ 의 침출온도에서 가장 효율적인 침출결과를 얻 을 수 있었으며, 1 시간 이상의 침출시간에서 $90 \%$ 정도 의 침출율을 얻을수 있으나, 염산침출의 경우에는 $50^{\circ} \mathrm{C}$ 이상의 침출온도에서는 20 분이내의 짧은 침출시간 내에 서도 $95 \%$ 이상의 높은 침출율을 얻을 수 있어 초산에 비 하여 매우 효율적인 침출용매 임을 확인할 수 있었다.

\section{2. $\mathrm{Fe}$ 성분 침출}

Fig. 9 와 Fig. 10 은 침출온도 $70^{\circ} \mathrm{C}$ 에서 침출용액의 산 농도에 따른 $\mathrm{Fe}$ 성분 침출결과를 보여주고 있으며 $\mathrm{Ca}$ 성분의 침출결과와 유사한 경향을 보이고 있다. 초산 


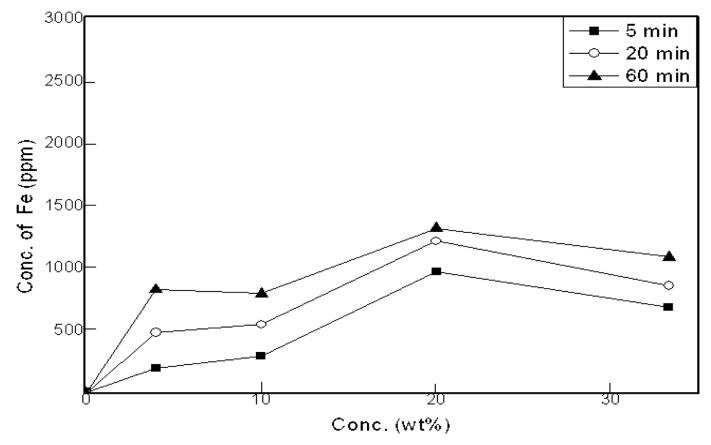

Fig. 9. Effect of acetic acid concentration in the extraction of $\mathrm{Fe}$ from the electric arc furnace $\operatorname{slag}\left(70^{\circ} \mathrm{C}\right.$, $120 \mu \mathrm{m}, 400 \mathrm{rpm}$ ).

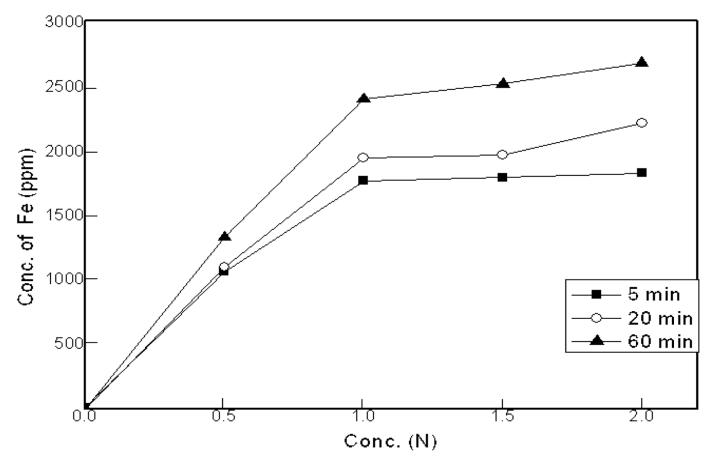

Fig. 10. Effect of hydrochloric acid concentration in the extraction of $\mathrm{Fe}$ from the electric arc furnace $\operatorname{slag}\left(70^{\circ} \mathrm{C}, 120 \mu \mathrm{m}, 400 \mathrm{rpm}\right)$.

의 경우 $20 \mathrm{wt} \%$ 에서 가장 침출이 많이 일어나고 있으 며, 염산침출의 경우는 침출용액 중의 염산농도가 증가 할수록 $\mathrm{Fe}$ 성분 침출율은 증가하는 경향을 보이고 있다. 침출반응시간이 짧은 반응초기에는 $1 \mathrm{~N}$ 이상의 염산농 도는 $\mathrm{Fe}$ 성분 침출에 큰 영향을 미치지 못하고 있으나 침출시간이 증가할수록 침출농도의 영향이 나타나 높은 농도에서의 $\mathrm{Fe}$ 침출이 보다 더 활발하게 진행되고 있다.

Fig. 11 과 Fig. 12 는 $30^{\circ} \mathrm{C}, 50^{\circ} \mathrm{C}$ 및 $70^{\circ} \mathrm{C}$ 의 침출온 도에서 침출시간에 따른 침출용액 중의 $\mathrm{Fe}$ 성분 농도의 변화량을 보이고 있다. 그림에서 보는 바와 같이 초산 의 경우, $30^{\circ} \mathrm{C}$ 의 침출온도에서는 4 시간 침출시 까지 침 출용액 중의 $\mathrm{Fe}$ 성분 농도는 꾸준히 증가하고 있으며, $50^{\circ} \mathrm{C}$ 와 $70^{\circ} \mathrm{C}$ 의 온도에서는 반응초기의 침출속도는 매 우 크나 20 분 이상에서는 침출율의 증가는 크지 않음 을 보이고 있다. 침출시간이 짧은 반응초기에는 $70^{\circ} \mathrm{C}$ 의 경우가 $50^{\circ} \mathrm{C}$ 보다 더 큰 침출속도를 보이나, 약 20 분 경과 후 부터는 겔상의 실리카 생성 때문에 침출반응속

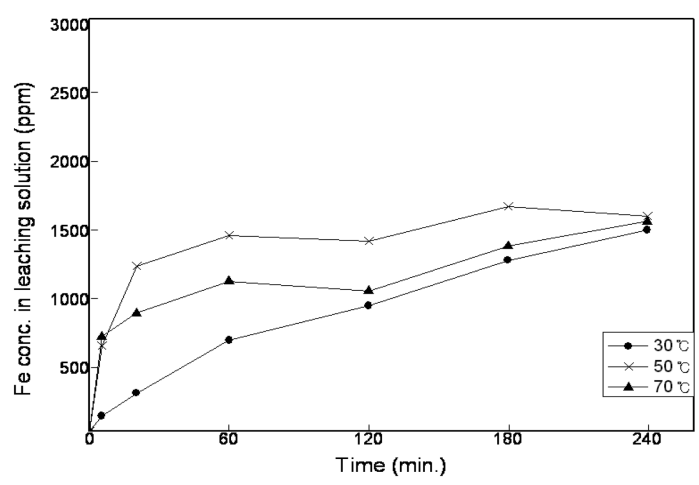

Fig. 11. Effects of leaching time on the extraction of $\mathrm{Fe}$ in the electric arc furnace slag $\left(33.3 \mathrm{wt} \% \mathrm{CH}_{3} \mathrm{COOH}\right.$, $120 \mu \mathrm{m}, 400 \mathrm{rpm})$.

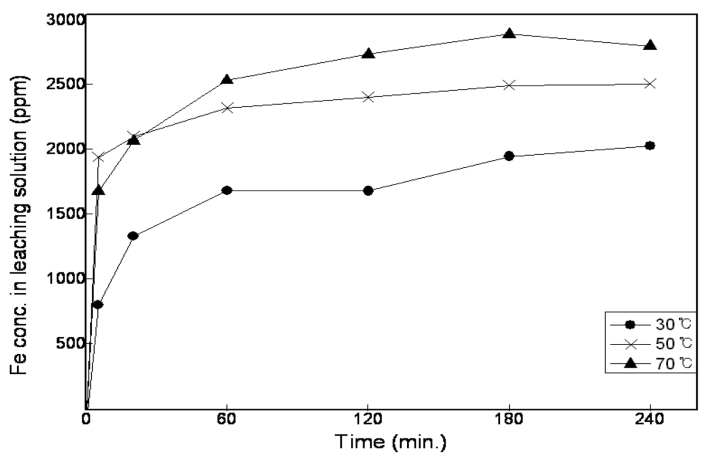

Fig. 12. Effects of leaching time on the extraction of $\mathrm{Fe}$ in the electric arc furnace $\operatorname{slag}(2 \mathrm{~N} \mathrm{HCl}, 120 \mu \mathrm{m}$, $400 \mathrm{rpm})$.

도의 급격한 감소를 보여 침출용액 중의 $\mathrm{Fe}$ 성분 농도 는 $50^{\circ} \mathrm{C}$ 의 경우보다 더 낮음을 보이고 있다. 초산침출 의 경우, 가장 효율적인 $\mathrm{Ca}$ 침출조건인 $50^{\circ} \mathrm{C}, 1$ 시간의 침출조건에서 $\mathrm{Fe}$ 성분의 침출농도는 약 $1,500 \mathrm{ppm}(42 \%$ 침출율) 정도이며, 모든 온도에서 4 시간 정도의 장시간 침 출 시에는 침출용액 중의 $\mathrm{Fe}$ 성분 농도는 약 $1,500 \mathrm{ppm}$ 정도로 유사한 값을 나타내고 있다. 염산침출의 경우도 침 출시간이 증가함에 따라 $\mathrm{Fe}$ 성분의 침출은 증가하는 경향 을 보이고 있다. 초기침출반응속도는 침출온도가 높을수 록 큰 값을 보이며 가장 효율적인 $\mathrm{Ca}$ 침출조건인 $50^{\circ} \mathrm{C}$, 20 분의 침출에서 $\mathrm{Fe}$ 성분의 침출농도는 약 $2,100 \mathrm{ppm}(58 \%$ 침출율) 정도이며, 2시간 이상의 침출시간에서는 $30^{\circ} \mathrm{C}$ 에 서는 약 $2,000 \mathrm{ppm}, 50^{\circ} \mathrm{C}$ 에서는 $2,500 \mathrm{ppm}, 70^{\circ} \mathrm{C}$ 에서는 $2,800 \mathrm{ppm}$ 정도로 초산에 비하여 $\mathrm{Fe}$ 성분 침출농도가 높 은 것을 관찰할 수 있었다.

이상의 실험결과로부터, 침출용액 중의 $\mathrm{Ca}^{2+}$ 의 탄산 
염화 과정에서 불순물로 작용할 수 있는 $\mathrm{Fe}$ 성분의 침 출을 최소화하면서 효율적인 $\mathrm{Ca}$ 침출율을 얻기 위해서 는 $50^{\circ} \mathrm{C}$ 침출조건에서 초산의경우는 1 시간 이내로, 염 산의 경우는 20 분 이내로 침출하는것이 바람직함을 알 수 있다.

\section{3. $\mathrm{CO}_{2}$ 에 의한 $\mathrm{Ca}^{2+}$ 의 탄산염화}

침출용액 중의 $\mathrm{Ca}^{2+}$ 이 용액 중에 투입되는 $\mathrm{CO}_{2}$ 가스에 의하여 $\mathrm{CaCO}_{3}$ 로 석출되기 위해서는 $\mathrm{CO}_{2}$ 가스의 용해에 의하여 $\mathrm{CO}_{3}{ }^{2-}$ 이 생성되고, 생성된 $\mathrm{CO}_{3}{ }^{2-}$ 이 $\mathrm{Ca}^{2+}$ 과 반응 하여 $\mathrm{CaCO}_{3}$ 로 석출되는 반응이 진행되어야 한다. ${ }^{8)}$

$\mathrm{CO}_{2}$ 가스가 수용액 중에 용해되어 $\mathrm{CO}_{3}{ }^{2-}$ 이 생성되는 반응의 진행을 단계별로 살펴보면, 우선 $\mathrm{CO}_{2}$ 가스가 수 용액 중에 용해되어 $\mathrm{H}_{2} \mathrm{CO}_{3}$ 를 생성하고(반응(1)), 생성 된 $\mathrm{H}_{2} \mathrm{CO}_{3}$ 는 반응(2)와 (3)에 의하여 분해되어 $\mathrm{CO}_{3}{ }^{2}$ 를 생성한다.

$$
\begin{aligned}
& \mathrm{CO}_{2(\mathrm{~g})}+\mathrm{H}_{2} \mathrm{O} \leftrightarrow \mathrm{H}_{2} \mathrm{CO}_{3(\mathrm{aq})} \\
& \mathrm{K}_{(\mathrm{H})}=29.4 \mathrm{~atm} / \mathrm{M} / \mathrm{L} \text { (Henry's constant) } \\
& \mathrm{H}_{2} \mathrm{CO}_{3(\mathrm{aq})} \leftrightarrow \mathrm{H}^{+}+\mathrm{HCO}_{3}^{-} \\
& \mathrm{K}_{2}=4.5 \times 10^{-7}(\mathrm{STP}) \\
& \mathrm{HCO}_{3}^{-} \leftrightarrow \mathrm{H}^{+}+\mathrm{CO}_{3}^{2-} \\
& \mathrm{K}_{3}=4.7 \times 10^{-11}(\mathrm{STP})
\end{aligned}
$$

반응 (1), (2), (3) 을 합한 전체반응식은 다음 (4)식 으로 표시된다.

$$
\mathrm{CO}_{2(\mathrm{~g})}+\mathrm{H}_{2} \mathrm{O} \rightarrow 2 \mathrm{H}^{+}+\mathrm{CO}_{3}^{2-}
$$

침출용액 중의 $\mathrm{Ca}^{2+}$ 이 반응(4)에 의하여 생성되는 $\mathrm{CO}_{3}{ }^{2-}$ 와 반응하여 $\mathrm{CaCO}_{3}$ 가 석출되는 반응은 다음과 같다.

$$
\begin{aligned}
& \mathrm{CaCO}_{3 \text { (calcite) }} \leftrightarrow \mathrm{Ca}^{+2}+\mathrm{CO}_{3}^{2-} \\
& \mathrm{K}_{\text {(sp) }}=5 \times 10^{-9} \text { (STP) (solubility product) }
\end{aligned}
$$

따라서 용액 중의 $\mathrm{Ca}^{2+}$ 이 $\mathrm{CO}_{2}$ 가스에 의하여 $\mathrm{CaCO}_{3}$ 로 석출되는 전체반응식은 (4)식과 (5)식으로 부터 다음 (6)식으로 표시될수 있다.

$$
\begin{aligned}
& \mathrm{CaCO}_{3}+2 \mathrm{H}^{+} \leftrightarrow \mathrm{Ca}^{2+}+\mathrm{CO}_{2(\mathrm{~g})}+\mathrm{H}_{2} \mathrm{O} \\
& \mathrm{Log} \mathrm{K}_{3}=9.842
\end{aligned}
$$

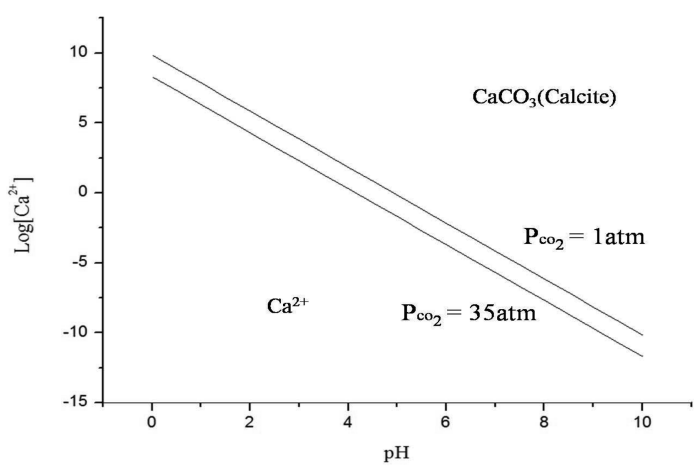

Fig. 13. Phase boundary between $\mathrm{Ca}^{2+}$ and $\mathrm{CaCO}_{3}$ (calcite).

$$
\begin{aligned}
& \text { 따라서, } \\
& \log \left[\mathrm{Ca}^{2+}\right]=9.842-\log \mathrm{Pco}_{2}-2 \mathrm{pH}
\end{aligned}
$$

Fig. 13 은 용액 중의 $\mathrm{Ca}^{2+}$ 농도와 $\mathrm{pH}$ 간의 관계에 따른 $\mathrm{Ca}^{2+}$ 과 $\mathrm{CaCO}_{3}$ (calcite)의 phase boundary를 보 이고 있다. 온도나 압력이 증가하면 각 반응의 평형상 수 값이 변화함에 따라 phase boundary는 좌측으로 이 동하게 되어 $\mathrm{CaCO}_{3}$ 안정구역이 넓어지게 된다. 염산수 용액을 사용한 전기로제강슬래그 침출연구에서 얻은 침 출용액 중의 $\mathrm{Ca}^{2+}$ 의 농도가 $2,500 \mathrm{ppm}(0.061 \mathrm{~mole})$ 정 도 일 경우 phase boundary 상의 $\mathrm{pH}$ 는 $\mathrm{Pco}_{2}$ 가 1 기압 및 35 기압 $(273 \mathrm{~K}$ 에서의 임계기압)에서 각각 5.53 및 4.76에 해당된다. 즉, 이론적으로는 침출용액 중의 $\mathrm{Ca}^{2+}$ 의 농도가 $2,500 \mathrm{ppm}$ 일 때 $\mathrm{CO}_{2}$ 가스 1 기압 하에서는 $\mathrm{pH} 5.53$ 이상의 조건에서 $\mathrm{Ca}^{2+}$ 는 $\mathrm{CaCO}_{3}$ 로 석출될 수 있을 것으로 기대되나 실제로는 반응속도가 매우 낮아 9 이상의 $\mathrm{pH}$ 조건이 요구된다. 반응식(5)에서 보는바와 같이, 용액 중의 $\mathrm{Ca}^{2+}$ 이온이 $\mathrm{CaCO}_{3}$ 로 석출하기 위해 서 필요한 $\mathrm{Ca}^{2+}$ 농도는 $\mathrm{CO}_{3}{ }^{2-}$ 농도가 증가될수록 낮출 수 있다. 즉 $\mathrm{Ca}^{2+}$ 의 탄산염화에 의한 $\mathrm{CO}_{2}$ 고정화를 효율적 으로 진행시키기 위해서는 $\mathrm{CO}_{2}$ 가스 투입 시 용액 중의 $\mathrm{CO}_{3}{ }^{2-}$ 의 농도를 증진시킬 필요가 있으며 이를 위하여 용 액의 $\mathrm{pH}$, 온도, 압력을 상승시키거나, $\mathrm{NaHCO}_{3}$ 와 같은 첨가제를 첨가하여 $\mathrm{HCO}_{3}{ }^{-}$의 농도를 증가시켜 $\mathrm{CO}_{3}{ }^{2-}$ 농도를 증가 시키는 방법도 제안되고 있다. ${ }^{8)}$

\section{4. 결 론}

본 실험을 통하여 얻은 연구결과를 요약하면 다음과 같다.

1. 전기로제강슬래그를 초산으로 침출하는 경우에는 
침출온도 $50^{\circ} \mathrm{C}$ 에서 가장 효율적으로 $\mathrm{Ca}$ 성분을 침출 할 수 있었으며 $33.3 \mathrm{wt} \%$ 초산농도에서 1시간 침출 시 약 $91 \%$ 침출율을 얻을 수 있었다. 또한, 염산수용액으로 침출하는 경우에는 초산의 경우보다 초기침출반응이 매 우 빠르게 진행되며 $50^{\circ} \mathrm{C}$ 의 $2 \mathrm{~N}$ 염산수용액에서 20 분 침출 시 $95 \%$ 이상의 침출율을 얻을 수 있었다.

2. $\mathrm{CO}_{2}$ 가스에 의하여 $\mathrm{CaCO}_{3}$ 로의 석출에 필요한 침출 용액 중의 $\mathrm{Ca}^{2+}$ 농도와 $\mathrm{pH}$ 간의 관계를 열역학적 자료를 통하여 검토한 결과, $\mathrm{Ca}^{2+}$ 농도가 $2,500 \mathrm{ppm}(0.061 \mathrm{~mole})$ 의 경우 $\mathrm{CO}_{2}$ 가스 1 기압 및 35 기압 하에서 $\mathrm{Ca}^{2+}$ 과 $\mathrm{CaCO}_{3}$ 상 간의 경계에 해당하는 $\mathrm{pH}$ 는 각각 5.53 과 4.76 의 결과를 얻었다.

3. 전기로제강슬래그의 $\mathrm{Ca}$ 성분 분리를 위한 산침출 과정에서 약 $2,000 \mathrm{ppm}$ 이상의 $\mathrm{Fe}$ 성분이 침출되어 침 출용액의 탄산염화 에 의한 $\mathrm{CaCO}_{3}$ 석출 시 불순물로 작용할 수 있으므로 순도가 높은 $\mathrm{PCC}$ 를 합성을 위해서 는 $\mathrm{Fe}$ 성분의 분리, 제거공정이 필요하다.

\section{사 사}

이 논문은 인천대학교 2009년도 자체연구비 지원에 의하여 연구되었으며, 이에 감사드립니다.

\section{尹 起 炳}

- PARIS 대학 재료공학 박사

• 현재 인천대학교 나노공학과 교수

\section{참고문헌}

1. Michael H. Huesemann, 2006; Can advances in science and technology prevent global warming?, Mitigation and Adaptation Strategies for Global Change, 11, pp. 5 39-577.

2. C.domingo et al., 2006; Calcite precipitation by a highpressure $\mathrm{CO}_{2}$ carbonation route, J. of Supercritical Fluids, 36 , pp. 202-215.

3. Johan Sipila et al., 2008; Carbon dioxide sequestration by mineral carbonation, Literature review update 2005-2007, Abo Academy University Faculty of Technology Heat Engineering Laboratory report VT 2008-1.

4. Teir, S et al., 2005; Production of precipitated calcium carbonate from calcium silicates and carbon dioxide, Energy conversion and Management, 46, pp. 2954-2979.

5. J.J. Huijgen et al., 2007; Cost evaluation of $\mathrm{CO}_{2}$ sequestration by aqueous mineral carbonation, Energy Conversion and Management 48, pp.1923-1935.

6. Sebastian Teir et al., 2007; Dissolution of steelmaking slags in acetic acid for precipitated calcium carbonate production, Energy, 32, pp. 528-539.

7. Sebastian Teir et al., 2007; Production of magnesium carbonates from serpentinite for long-term storage of $\mathrm{CO}_{2}$, Int. J. Miner. Process, 85, pp. 1-15.

8. Zhong-Ying Chen et al., 2006; Chemistry of aqueous mineral carbonation for carbon sequestration and explabation of experimantal results, Environmental Progress, 25, No.2, pp. 161-166. 